\title{
Market Reaction to Health Care Law: An Event Study
}

\author{
Musab Ababneh (Corresponding author) \\ Earl G. Graves School of Business, Morgan State University \\ 1700 E. Cold Spring Lane, Baltimore, Maryland 21251, United States
}

Tel: 1-443-739-0695Ｅ-mail: ma29980@yahoo.com

\author{
Alex Tang \\ Earl G. Graves School of Business, Morgan State University \\ 1700 E. Cold Spring Lane, Baltimore, Maryland 21251, United States \\ Tel: 1-443-885-3175 E-mail: alex.tang@morgan.edu
}

Received: March 06, 2013 Accepted: March 25, 2013 DOI: 10.5296/ijafr.v3i1.3356

\begin{abstract}
We investigate the effect of the U.S. Supreme Court's decision to uphold President Obama's health care reform (Patient Protection and Affordable Care Act), and other reform-related events, on the stocks of impacted firms. More specifically, we use an event study methodology to compute cumulative average abnormal returns (CAARs) for health insurance companies, hospitals, brand-name drug makers, and generic drug makers. Overall, we find that the law has a negative effect on health insurance companies, and on generic drug makers. On the other hand, it has a positive effect on hospitals and on brand-name drug makers.
\end{abstract}

Keywords: Market reaction, Health care law, Cumulative abnormal return, Event study 


\section{Introduction}

Several researchers have examined and found an association between the U.S. Supreme Court decisions and the capital market (e.g., Abraham \& Voos, 2005; Freedman \& Stagliano, 1991; McWilliams, Turk \& Zardkoohi, 1993; Mullin, Mullin \& Mullin, 1995). Such researchers have documented evidence showing that market investors react (positively or negatively) to decisions made by the U.S. Supreme Court.

One recent decision made by the U.S. Supreme Court concerns the health care system in the United States. The Supreme Court has decided to uphold President Obama's Health Care Reform (Officially known as the Patient Protection and Affordable Care Act). The Act has drawn a lot of attention and national debate as to whether it is beneficial or harmful to U.S. economy. Republicans maintain that it will harm the economy (GOP, 2012) while most Democrats think otherwise (Terkel, 2012).

The reform has implications for health insurance companies (Jayakumar \& Kliff, 2012), hospitals (Krista, 2012), brand-name drug makers (Abelson, 2010), generic drug makers (Abelson, 2010) as well as the general public. It requires all Americans to have health insurance coverage by 2014 or be penalized (Amadeo, 2012). It bans insurance companies from denying coverage to people with pre-existing conditions (Kristof, 2012). The Act is expected to help hospitals generate more revenues. This is true because more patients will seek hospitalization if they need to as they will have insurance coverage (Kristof, 2012). In addition, it provides brand drug makers with incentives and subjects them to less governmental regulation (Abelson, 2010). Nonetheless, the reform seems to have a negative effect on generic drug companies (Kristof, 2012).

The purpose of this study is to examine the effect of the Supreme Court decision to uphold President Obama's Health Care Reform Act on the stocks of impacted firms, which include: health insurers, hospitals, brand-name drug makers, and generic drug makers (We have obtained the list of these companies from Zacks Investment Research, a leading stock investment and analysis firm).

This study is important and timely because it examines an issue, namely the health care law, which has sparked the national attention. Some analysts and industries such as brand-name pharmaceutical industry and American Hospital Association maintain that it is beneficial while others such as health insurers argue otherwise. We conduct this study using stock market data to quantitatively discern whether the new law is beneficial or harmful to the pertinent industries.

We consider the Supreme Court decision as our main event because many entities have challenged the new law's constitutionality and tried to repeal it (GOP, 2012) until the Supreme Court upheld it. In other words, without the Supreme Court's decision to uphold the law, it would have fallen apart. However, we have decided to examine the effect of other major law related events (e.g., President's signature of the law, requiring insurers to issue rebates, etc.) to provide a more comprehensive analysis of the law and its impact. By providing a more comprehensive analysis, we hope to enrich the national debate on the new 
law and its effect on impacted firms.

We have used an event study methodology to conduct our study. Generally, our results indicate that the new health care reform has a negative effect on health insurance firms and generic drug makers. However, the new law generally affects hospitals and brand-name drug makers positively.

The layout of the paper is as follows: Section 2 discusses major studies that have examined the impact of U.S. Supreme Court decisions on stocks. Section 3 reviews past literature and develops main hypotheses. Section 4 describes our study methodology and briefly describes the market model. Section 5 outlines the main findings. Section 6 concludes the paper.

\section{The Effect of the U.S. Supreme Court Decisions on Stock Market}

Many scholars have documented the effect of the decisions which the Supreme Court makes on the stock market. For example, Freedman and Stagliano (1991) have studied the impact of the Supreme Court's decision to allow Occupational Safety and Health Administration (OSHA) to impose more stringent rules and regulations. Such rules and regulations have aimed at reducing dust emissions in the cotton textile industry. The results of their study show that such a decision "had a major economic impact on the industry" (Freedman \& Stagliano, 1995 , p.68) as it requires textile manufacturers to invest in expensive clean-up equipment which would reduce their already low profit margins and increase their costs.

More precisely, Freedman and Stagliano (1995) point out that the stock prices of firms that operate in the cotton textile and the knitting industries have gone down in the first two days following the Supreme Court's decision. This decline in stock prices shows that investors react negatively to the new OSHA emission reduction's mandate. In addition, they notice that the effect of the Supreme Court's decision is stronger when the firm does not disclose any information on the expected impact of the new mandate on its operations.

Mullin, Mullin, and Mullin (1995) have studied the reaction of the stock market to several events. The events include the Supreme Court decision not to dissolve U.S. Steel. The Court has concluded that U.S. Steel does not constitute a monopoly. Their results indicate that "when the Supreme Court ordered re-argument of the U.S. Steel case, U.S. Steel responded [stocks return] in a positive and statistically significant manner" (Mullin et al., 1995, p.323). They also study the event of the Supreme Court's ruling to affirm the district court's decision in U.S. Steel's favor. They notice that such a ruling has a positive and significant effect on U.S. Steel's stock returns. Mullin et al. (1995) also argue that the stocks of independent producers of steel (competitors of U.S. Steel) has a positive $4.26 \%$ excess return. On the other hand, stocks of street railways (consumers of steel) have witnessed a negative $2.55 \%$ excess return during the week when the Supreme Court decided in favor of U.S. Steel.

In another study, Abraham and Voos (2005) examine the effect of the Supreme Court decisions which include the Health Care \& Retirement Corporation of 1994 and Kentucky River of 2001 cases. Simply stated, the two cases were filed by nurses and nursing professionals respectively to be granted the right to organize and join a union. The Supreme 


\section{Mll Macrothink}

International Journal of Accounting and Financial Reporting ISSN 2162-3082

Court has decided that these two categories of workers are considered supervisors who are not allowed to unionize. Abraham and Voos (2005) conclude that the market investors react to the Supreme Court decision positively by sending the stock prices up. They also notice that the market is more responsive to Kentucky River's case ruling. They contend that the stronger reaction means that market investors consider Kentucky River's case as one that has a more significant effect on allowing professionals to organize.

McWilliams, Turk, and Zardkoohi (1993) have conducted an event study to examine the effect of the Supreme Court's decisions, for companies involved in merger negotiation cases, on the stock market. They contend that market participants consider the Supreme Court decisions as impactful. This is true because the results of their study indicate that affected firms' (engaged in merger negotiations) value has declined. Cumulative abnormal return (CAR) of these firms has declined by $1.38 \%$ during the two days of the Supreme Court' case argument, and the following day. CAR has also declined by $1.52 \%$ during a six-day window; which includes the case argument and five days after the argument. Furthermore, McWilliams, Turk, and Zardkoohi (1993) find that the market reacts more strongly to close Supreme Court case arguments than it does to lopsided ones which allow for public access and information leakage or anticipation.

\section{Literature Review and Hypotheses Development}

\subsection{Description of the Health Care Reform}

The health care reform is officially called the Patient Protection and Affordable Care Act (Amadeo, 2012). The act requires the estimated 30 million Americans who are uninsured to have insurance coverage by 2014 or pay a tax penalty (Amadeo, 2012). In 2014, the penalty will be $\$ 285$ per family or $1 \%$ of total income, whichever is greater (Kavilanz, 2012), and it will increase to $\$ 2,085$ a family or $2.5 \%$ of income, whichever is greater, in 2016 (Kavilanz, 2012). Those with insurance coverage will be allowed to keep the same plan, cover their dependents until the age of 26 , and enjoy preventive services such as mammograms and colonoscopies without paying a deductible, co-pay or co-insurance (Kavilanz, 2012).

The new law requires health insurance companies to spend at least $80 \%$ of customers' premiums on medical services or rebate the difference to the consumer (Amadeo, 2012). In addition, insurance companies will not be allowed to deny coverage to any person with a pre-existing condition (Kristof, 2012), drop individuals if they become seriously ill, or set a maximum lifetime dollar amount on insurance benefits (Amadeo, 2012).

The law requires states to establish the so called "health insurance exchanges" which are a web-based marketplace that allows uninsured/underinsured customers to purchase subsidized health insurance (Kavilanz, 2012), and to find out if they qualify for Medicaid assistance or tax credit (Amadeo, 2012). The states will receive federal funding to help them set up the exchanges and cover low income individuals and children through the Medicaid program (Amadeo, 2012). Senior citizens on a Medicaid plan will enjoy free preventive care and wellness services, and the "donut hole" which requires seniors to pay for their medicine fully, will be eliminated (Amadeo, 2012). 


\section{MlMacrothink}

International Journal of Accounting and Financial Reporting ISSN 2162-3082 2013, Vol. 3, No. 1

Businesses that employ 50 or more workers must provide them with some sort of health insurance coverage or pay a penalty (Kavilanz, 2012). The penalty is $\$ 2000$ per worker except for the first 30 workers (Amadeo, 2012). All businesses that employ less than 100 employees will be allowed to utilize the health insurance exchanges to shop for more affordable coverage (Amadeo, 2012). In addition, business firms with 25 workers or fewer will receive a $35 \%$ tax credit, which will go up to $50 \%$ by 2014 , provided that they provide health insurance to their employees (Amadeo, 2012). Companies which provide early retirees age 55-64 with health insurance will receive aid from the federal government (Amadeo, 2012).

Table 1 below highlights the major events associated with the health care reform since 2010 . On March 23 of 2010, President Obama signed the health care reform bill into law and some of the law's provisions began to go into effect. For example, in July of 2010, the law required health insurance companies in the U.S. to start covering individuals with pre-existing medical conditions. On January $1^{\text {st }}$ of 2011 , both brand-name and generic pharmaceutical companies were required to offer seniors discounts on their medications to close the coverage gap known as "donut hole" which some seniors fall into because of Medicare spending limitations (Favole, 2010). On December $7^{\text {th }}$ of 2011, the law required insurance companies to refund any unused premiums known by insurers as the "Medical Loss Ratio" or MLR (Young, 2012). (We discuss donut hole and MLR in more depth in literature review and hypotheses development section). After a national debate of whether the new law is constitutional or not, the Supreme Court affirmed its constitutionality in June of 2012. On October $1^{\text {st }}$ of 2012, the law required all hospitals to participate in the so-called "Value-Based Purchasing Program" which is designed to enhance hospitals' efficiency and patients' satisfaction (Mukherjee, 2012).

Table 1: Health care reform major events and dates

\begin{tabular}{|l|l|}
\hline Event & Date \\
\hline President Obama signed the law & $3 / 23 / 2010$ \\
\hline Requiring insurers to cover pre-existing conditions & $7 / 1 / 2010$ \\
\hline Requiring drug companies to offer seniors discounts (Donut hole) & $1 / 1 / 2011$ \\
\hline Requiring insurers to issue rebates (MLR) & $12 / 7 / 2011$ \\
\hline Supreme Court upheld the law & $6 / 28 / 2012$ \\
\hline Creating hospital Value-Based Purchasing Program & $10 / 1 / 2012$ \\
\hline
\end{tabular}

\subsection{The Effect of Health Care Reform on Health Insurance Firms}

Jayakumar and Kliff (2012) argue that the release of the Supreme Court's decision to uphold 


\section{MlMacrothink}

International Journal of Accounting and Financial Reporting ISSN 2162-3082 2013, Vol. 3, No. 1

President Obama's Health Care Reform has a negative impact on health insurance companies. This negative effect is anticipated as the new health law requires health insurance firms to use a completely new business model instead of the model which has been in use for decades (Jayakumar \& Kliff, 2012). Such a shift in models increases health insurance firms' costs and reduces their profits (Hamilton \& Tangel, 2012). Also, health insurance companies' investors are uncertain about the future implications of the new reform and its impact on profits. Thus,

they are reacting to the news that the new reform will be detrimental to health insurers (Hamilton \& Tangel, 2012).

The new law is expected to lower health insurance companies' profit margin through increased regulation. For instance, Young (2012) points out that some of the aims of the new law include requiring health insurance companies to charge lower premiums, to cut advertising costs, and to abstain from maximizing profit. Also, Kristof (2012) indicates that health insurance companies will be required to justify any rate increase before it can go into effect.

The negative impact of the new health care law on health insurance companies is manifested by health insurance companies' attempt to unite and defeat the law. They have maintained that the law does not improve health care quality or cut costs (Kavilanz, 2010). They contend that the law will raise premiums on individuals as well as on small businesses (Kavilanz, 2010). Health insurance companies also argue that the law raises health insurance firms' taxes by billions of dollars annually (Kavilanz, 2010).

Ungar (2012) reports that the health industry's lobby known as "American Health Insurance Plans" has spent more than $\$ 100$ million on advertisement. The advertising aimed at convincing the general public that the new law is detrimental and that it needs to be defeated. The above discussion leads to the following hypothesis:

H1a. Cumulative Average Abnormal Return (CAAR) for health insurance companies upon the President's signing of the law is negative.

Starting in 2014, health insurance companies will no longer be able to deny coverage to individuals with pre-existing medical conditions (Kristof, 2012). These conditions may include diseases such as cancer, diabetes, and heart problems. Such health problems are chronic and very costly to treat. Before the new health care law, insurance companies have limited their spending on treating people with pre-existing conditions (Baghaeimehr, 2012). Also, insurers have imposed higher premiums on patients with pre-existing conditions (Baghaeimehr, 2012).

It is reported that some health insurance companies have denied coverage to almost 650000 Americans because of a pre-existing condition (DI Editorial Board, 2012). They have also turned away one of seven insurance seekers for the same reason (DI Editorial Board, 2012). The new law has changed these rules which insurance companies set to maximize profits. Insurance companies are no longer allowed to set lifetime dollar limits or charge higher premiums if an individual has pre-existing conditions (Baghaeimehr, 2012). The law also prohibits insurers from denying children coverage if they have a pre-existing condition (DI 
Editorial Board, 2012). Now, they are required to provide the same coverage to all subscribers regardless of their health status for the same price (Baghaeimehr, 2012).

Knowing that 50 to 129 million Americans have some sort of pre-existing health condition, that almost 25 million individuals with pre-existing medical problems are uninsured, and that 86 percent of older Americans between the ages of 55 and 64 have pre-existing conditions (U.S. DHHS, 2011), insurance companies see more expenses and less profit because of this provision.

Based on the above discussion, we hypothesize that:

H1b. Cumulative Average Abnormal Return (CAAR) for health insurance companies upon the enacting of the pre-existing conditions provision of the health care law is negative.

The insurance industry has been worried about the negative effect of the law on their profits particularly the part of the law which requires them to absorb what is known as "Medical Loss Ratio" or MLR. The new law requires health insurance companies to spend at least 80 percent of premiums collected from customers on medical expenditures, and to refund any unused premiums (The difference between $80 \%$ and what they actually spend on health related expenses). Health insurance companies refer to this unused premium refund as "Medical Loss Ratio" as they consider it to be lost profit (Young, 2012).

Because of the negative impact MLR has on health insurance companies, some states are worried that insurers will leave their markets (Insurance Journal, 2012). Therefore, the government has decided to grant these states a temporary waiver from the MLR (Insurance Journal, 212). In addition, MLR is expected to cost insurers billions of dollars in rebates each year (Insurance Journal, 2012). Thus, insurance companies are looking for ways to reduce their expenses to compensate for MLR. For example, it is reported that health insurance companies feeling the negative impact of MLR are likely to start paying a particular group, namely, independent insurance agents less money (Insurance Journal, 2012) and find other ways to lower their expenses such as advertising costs (Young, 2012).

The above discussion leads to the following hypothesis:

H1c. Cumulative Average Abnormal Return (CAAR) for health insurance companies upon the enacting of the MLR provision of the health care law is negative.

Since the Supreme Court decision has only affirmed the constitutionality of the new law, we expect that both events (The Supreme Court decision and President's signature of the law) will have the same effect. Thus, we also predict that (We use the same logic to establish Supreme Court decision and President's Signature events' hypotheses for the remaining groups).

H1d. Cumulative Average Abnormal Return (CAAR) for health insurance companies upon the release of the Supreme Court decision to uphold the law is negative.

\subsection{The Effect of Health Care Reform on Hospitals}

Hospitals have absorbed the cost of offering medical treatment to individuals with no health 


\section{Mll Macrothink}

International Journal of Accounting and Financial Reporting ISSN 2162-3082 2013, Vol. 3, No. 1

coverage, particularly in the case of emergencies, for many years. The new law requires all citizens to have health insurance and consequently insurance companies will be responsible for paying the bills of their customers. As such, hospitals will no longer have to incur the expense of treating uninsured patients and their profits are likely to rise (Jayakumar \& Kliff, 2012). Additionally, Hamilton and Tangel (2012) suggest that hospitals would gain more customers who will be more willing to get hospitalized if they need to and they will be able to pay their bills through their insurers.

Kristof (2012) considers hospitals as the only winner of the new law because the new reform helps them get paid for the medical care they provide to their patients. These patients will be required to have some sort of health insurance coverage through an insurer which will pay the hospitals. Britt and Lesova (2012) describe the new law as a boon or a gift from the Supreme Court to hospitals and their stocks. Britt and Lesova (2012) also suggest that hospitals will do better because of the anticipated 30 million individuals who will have insurance coverage by 2014. These individuals will increase hospital earnings by decreasing the $20 \%$ of hospital expenses that go uncompensated each year due to lack of health insurance coverage.

Rogoff and Yerramalli (2012) report that the American Hospital Association has supported the new health care law because of the expected increase in their revenues. Brubaker, Burling, Sell, and Von Bergen (2012) report that top executives of many hospitals are happy about the new law because they expect to reduce bad debts which result from uninsured patients. In addition, many analysts argue that hospitals are a big winner of the new law (Krantz, 2012) and that they "celebrated the ruling" in anticipation of treating insured and able to pay patients (Smith, 2012).

Based on the above discussion, we hypothesize that:

H2a. Cumulative Average Abnormal Return (CAAR) for hospitals upon the President's signing of the health care law is positive.

H2b. Cumulative Average Abnormal Return (CAAR) for hospitals upon the release of the Supreme Court decision is positive.

Under the new health care law, a new hospital program known as "The Hospital Value-Based Purchasing Program" will be implemented. It requires hospitals to improve the quality of their services and medical care (Mukherjee, 2012). The program also aims at lowering patient readmission's rate and increasing patients' satisfaction (Mukherjee, 2012).

To ensure that hospitals comply with the program's requirements, the government has linked Medicare hospitals' funding to patients evaluations of hospitals and to certain quality standards they must meet (Mukherjee, 2012). The government will lower Medicare funding for hospitals with higher readmission rates (Mukherjee, 2012).

As such, many health professionals consider the program to be advantageous for hospitals as it encourages them to increase efficiency (Mukherjee, 2012), cut spending, forgo unneeded medical care, and provide better care to their patients (Horwitz \& Levy, 2012). Rogoff and Yerramalli (2012) contend that the program will increase hospitals' liquidity. Hospitals which 
meet performance standards will experience an increase in their Medicare and Medicaid payments (Rogoff \& Yerramalli, 2012). The program will also help hospitals use standardized and more efficient delivery systems (Deschenes, 2012) and thus reduce operation costs (Deschenes, 2012). Thus, we formally hypothesize that:

H2c. Cumulative Average Abnormal Return (CAAR) for hospitals participating in the Value-Based Purchasing Program is positive.

\subsection{The Effect of Health Care Reform on Brand-Name Pharmaceutical Companies}

Many analysts consider the new health care reform to be beneficial (except donut hole and fees requirement) for the brand-name pharmaceutical companies (Abelson, 2010; Baker, 2012; Beeson \& Todd, 2012; Shannon, 2010). Abelson (2010) argues that the new law requiring all Americans to be insured by 2014 will work as a catalyst for the estimated 30 million new customers to go to hospitals. Also, patients will visit their doctors more often and thus purchase more medicine from brand drug makers. The brand-name pharmaceutical industry expects increased drug sales and billions of dollars in additional profit (Abelson, 2010). In addition, after modifying the law, brand-name drug makers will not be subject to price controls or to more governmental regulations as it was initially proposed (Abelson, 2010).

Because of these benefits, branded drug makers have spent about $\$ 100$ million on advertising and marketing efforts to help promote the new health care law (Abelson, 2010). Beeson and Todd (2012) point out that the brand-name pharmaceutical companies have lobbied policy makers. The brand-name drug makers pushed to pass a comprehensive health care reform back in 2009 due to the anticipated increase in their medicines and medical devices sales and to ensure cutting as beneficial of a deal as possible with the federal government (Baker, 2012). In fact, some drug makers such as Johnson \& Johnson have been pleased with the Supreme Court's decision to uphold the health care law (Beeson \& Todd, 2012). Johnson \& Johnson considers the law as a vehicle which will improve the quality of health care in the United States (Beeson \& Todd, 2012).

Shannon (2010) reports that the brand-name pharmaceutical companies have supported the law since it was first enacted in 2010. The brand-name pharmaceutical firms support the law because of the expected gain of millions of new customers, limited governmental intervention, and special incentives such as long term market exclusivity for particular drugs.

Based on the above discussion, we hypothesize that:

H3a. Cumulative Average Abnormal Return (CAAR) for brand-name pharmaceutical companies upon the President's signing of the law is positive.

The new health care law requires pharmaceutical companies to offer seniors a $50 \%$ discount on brand-name drugs and other discounts on generic prescription medicine while they are in the so-called "donut hole" (Sebelius, 2010). The donut hole refers to a gap in Medicare Part D Prescription-drug coverage (Favole, 2010). Medicare participants, who reach the maximum 
amount allowed for their drug purchases, have to pay out of pocket for their medicine (Sebelius, 2010).

The new law mandates both brand-name and generic drug makers to offer seniors discounts to close the donut hole by 2020 (Sebelius, 2010). For instance, seniors pay $50 \%$ for brand-name drugs and 86\% for generics in 2012 (Health Care, 2010). In 2013, they pay $47.5 \%$ for brand-name drugs and $79 \%$ for generics. By 2020, they will pay $25 \%$ for brand-name medicines and 25\% for generics (Health Care, 2010).

Drew and Burt (2011) argue that offering seniors the discounts to close the coverage gap has a negative effect on drug makers. Khimm (2009) describes it as expensive to finance. Mellor (2009) argues that closing the donut hole and enacting the health care law limit pharmaceutical companies' ability to keep charging Americans more money for their medicines (Mellor, 2009). By closing the donut hole, the pharmaceutical industry will lose billions of dollars of reimbursed government subsidies for seniors' medicines (Mellor, 2009). Favole (2010) suggests that closing the donut hole will cost drug makers about $\$ 32$ billion over the next 10 years. In addition, drug makers have to reduce their medicine prices and cut their profit margins to comply with the law (Silverman, 2012). Based on the discussion above, we contend that:

H3b. Cumulative Average Abnormal Return (CAAR) for brand-name pharmaceutical companies upon the enacting of the donut hole provision of the health care law is negative.

As we have argued previously, the Supreme Court decision and the President's Signature events have the same effect and they complement each other. Thus, we also contend that:

H3c. Cumulative Average Abnormal Return (CAAR) for brand-name pharmaceutical companies upon the release of the Supreme Court decision is positive.

\subsection{The Effect of Health Care Reform on Generic Pharmaceutical Companies}

Generic drug makers are likely to be concerned about the negative implications the new health care reform will have for them (Ignjatovic, 2010). The law guarantees branded drug makers a12-year market exclusivity for branded biologics as opposed to the typical 5 to 7 year period (Ignjatovic, 2010). This exclusivity puts generic drug makers at a competitive disadvantage. In a reaction to the exclusivity provision, the Generic Pharmaceutical Association has stated that the law should help needy patients get access to affordable drugs rather than expensive medications such as biologics with a very long exclusivity (Abelson, 2012).

Policy makers have also favored brand drug makers and removed a provision which could have put more restrictions on patent settlement agreements (Abelson, 2012). Also, the law provides generic drug makers with very little help compared to brand drug markers (Reuters, 2012). Moreover, policy makers have omitted the so called "pay for delay" provision in an effort to convince brand drug makers to endorse the new law. The removal of this provision has come at the expense of generic drug makers which were supposed to be compensated by brand drug makers if they delay bringing a rival medicine to the market (Trager, 2010). 


\section{Macrothink}

International Journal of Accounting and Financial Reporting

Based on the previous discussion, we hypothesize that:

H4a. Cumulative Average Abnormal Return (CAAR) for generic drug makers upon the President's signing of the law is negative.

Since both brand-name and generic drug makers are required to close the donut hole, the same arguments we have laid out earlier hold for generic drug companies. Thus, we hypothesize that:

H4b. Cumulative Average Abnormal Return (CAAR) for generic drug companies upon the enactment of the donut hole provision of the health care law is negative.

As we have indicated earlier, the Supreme Court decision and the President's Signature events have the same impact and they complement each other. Thus, we hypothesize that:

H4c. Cumulative Average Abnormal Return (CAAR) for generic drug makers upon the release of the Supreme Court decision is negative.

Table 2 below summarizes our hypotheses. It provides the expected CAAR sign for each of the hypotheses.

Table 2: Expected CAAR per hypotheses

\begin{tabular}{|l|l|l|l|l|}
\hline Event & Insurers & Hospitals & Branded & Generic \\
\hline President Obama signed the law & - & + & + & - \\
\hline $\begin{array}{l}\text { Requiring insurers to cover pre-existing } \\
\text { conditions }\end{array}$ & - & & & \\
\hline Requiring drug makers to offer discounts & & & - & - \\
\hline Requiring insurers to issue rebates (MLR) & - & & & \\
\hline Supreme Court upheld the law & - & + & + & - \\
\hline Creating hospital Value-Based Purchasing & & + & & \\
\hline
\end{tabular}

\section{Study Methodology and Sample}

In studying the effect of the Supreme Court's decisions on the stocks of the firms affected by such decisions, several researchers have used the event study methodology (e.g., Abraham \& Voos, 2005; Freedman \& Stagliano, 1991; McWilliams et al., 1993). We have used the event study methodology to conduct our analysis. Based on this methodology, we contend that the market is efficient as it has the ability to incorporate new information into the price of stocks (Ball \& Brown, 1968; Fama, 1970; Fama, Fisher, Jensen, \& Roll, 1969). 
We have used Eventus (Fama-French Basic Event Study Daily) to compute cumulative abnormal return (CAR) for our events (e.g., Supreme Court decision date) or 0 and the day following it or 1. Basic Event Study is the most commonly used event study and it helps researchers examine the effect of a single event date on each firm in the study sample (Events Study, 2012). Our study examines the impact of single events on firms' stocks. Also, we have chosen Eventus Fama-French model because it controls for three variables (firm size, book-to-market ratio, and momentum which refers to past returns and was added by Jegadeesh and Titman in 1993). Kothari and Warner (2005) argue that researchers should control for these variables when conducting an event study. We report Generalized Z scores as reported by Fama-French Eventus model to test the significance of our hypotheses.

The event window should be as short as possible (e.g., a day or two) around the event. This is true because other factors that may influence stock returns are eliminated, and a more accurate analysis of the impact of the event of interest on stocks is made (Boehmer, Broussard, \& Kallunki, 2002). On the other hand, the period preceding the event date (estimation period) could start 200 trading days before the event (Boehmer et al., 2002; Freedman \& Stagliano, 1991) and end almost 46 trading days before the same event takes

place (Golec \& Vernon, 2012). Boehmer et al. (2002) also argue that this period could run from 250 days to 20 days before the event. In other words, it has to be long enough and far from the event date and no one period is considered optimal. Peterson (1989) and Armitage (1995) argue that an estimation period of 100-300 days is considered sufficient for parameters' estimation. We use $(-100,-20)$ as our estimation window.

We have used CRSP database to obtain PERMNO number for each firm in each of the four groups of firms we examine, entered PERMNO numbers along with the date of the event examined (e.g., 06/28/2012 for Supreme Court decision) into a Notepad file, and then uploaded them into Eventus to compute CAAR for each group.

Our sample is obtained from Zacks Investment Research website. We have chosen Zacks because it is considered a leading investment research firm which mainly focuses on stock research and analysis (Zacks, 2012). Our study sample consisted of all firms listed on Zacks database and it included: 15 health insurance companies, 11 Hospitals, 13 brand-name drug companies and 10 generic drug companies.

\subsection{The Market Model}

Eventus uses the market model to compute expected return of companies' stocks given the risk of those stocks (beta) and the market return on a specific day (We have omitted the control variables for simplicity). The market model parameters ( $\alpha$ and $\beta)$ are estimated using daily returns of a time period which precedes an event (e.g., The Supreme Court decision on 06/28/2012). This estimation period should be long enough, far away from the event date, and it should end a few weeks before the event date (Boehmer et al., 2002). The market model can be expressed as:

$\mathrm{R}_{\mathrm{it}}=\alpha_{\mathrm{i}}+\beta_{\mathrm{i}} \mathrm{R}_{\mathrm{mt}}+\mathrm{e}_{\mathrm{it}} \quad$ where: 


\section{Macrothink}

Rit : firm i's daily stock return on day t.

Rmt: market return on day t represented by the CRSP equally-weighted index return.

ai: regression model intercept for firm i

$\beta i$ : market model parameter for firm i.

eit : the error term for firm $i$ at time $t$.

The normal or expected return $E[R]$ on a specific day $t$, for stock $i$ is measured as:

$\wedge \wedge$

$\mathrm{E}\left[\mathrm{R}_{\mathrm{it}}\right]=\alpha_{\mathrm{i}}+\beta_{\mathrm{i}} \mathrm{R}_{\mathrm{mt}}$

The coefficients in the market model equation are estimated over the trading days which precede the event window. They are used to calculate, Ait, which is the risk-adjusted (also known as abnormal) return on a specific day $t$ for firm $i$ as:

Ait $=R_{\text {it }}-E\left[R_{i t}\right]=R_{i t}-\alpha_{i}-\beta_{i} R_{m t}$

Using Eventus, we compound these abnormal returns over the days of the event period to calculate cumulative abnormal return (CAR) for each firm and average CAR for each group of firms affected which yields CAAR or cumulative average abnormal return.

It is worthwhile to mention that we as well as other researchers who use the market model or event study methodology do not attempt to predict the level of any market indicator such as Dow Jones Industrial Average or NASDAQ (Abraham \& Voos, 2005). Rather, the model helps researchers investigate the movement in stocks of firms affected by an event relative to that of the overall market (Abraham \& Voos, 2005). Thus, we report abnormal stock returns (given an event such as the Supreme Court's decision) of impacted firms over the event window which yields cumulative abnormal returns (CARs) for such firms. CAR represents the difference between the actual return of a stock in the event window and the normal or expected return in the absence of the event (Boehmer et al., 2002).

\section{Results}

Table 3 below presents the results of our analysis of the effect of the health care law on health insurance companies. It presents cumulative average abnormal returns (CAARs) and Generalized Z scores for the events we have tested.

Our results indicate that $\mathrm{H} 1 \mathrm{a}$ is supported. CAAR is negative and highly significant as the $\mathrm{Z}$ score indicates. This means that the enacting of the law after the President's signature has a negative effect on health insurers as we have predicted. H1b and H1c are also supported as CAARs are negative and significant. Requiring health insurance companies to cover individuals with pre-existing medical conditions without allowing them to set a lifetime limit 


\section{Ml Macrothink}

International Journal of Accounting and Financial Reporting

ISSN 2162-3082

2013, Vol. 3, No. 1

has a negative impact on them. Also, requiring insurers to refund any unused premiums (Medical Loss Ratio) lowers insurers' bottom line and profits and negatively affects them.

While H1d is not supported, CAAR is negative as we have expected. We cautiously contend that the Supreme Court decision may have negatively impacted health insurance firms, but such an impact is not as severe as it has been initially anticipated. Perhaps health insurers have realized this fact after implementing the law for nearly two years. Notice that H1a (Passage of the law) is supported and CAAR is negative and highly significant. A high level of uncertainty about the exact future implications of the law may have caused this highly significant negative effect. But when the level of uncertainty is reduced after two years, the negative effect may have been reduced.

Table 3: Health insurance firms' CAAR and Gen Z scores

\begin{tabular}{|l|l|l|}
\hline Event & CAAR \% & Gen Z \\
\hline President Obama signed the law & -1.28 & $-2.113^{*}$ \\
\hline Requiring insurers to cover pre-existing conditions & -1.16 & $-2.788 * *$ \\
\hline Requiring insurers to issue rebates & -1.07 & $-1.327 * * *$ \\
\hline Supreme Court decision & -2.43 & -1.155 \\
\hline
\end{tabular}

$*$ Significant at 0.05 level ** 0.01 level $* * * 0.1$ level

Table 4 shows CAARs and Generalized Z scores for our hospitals' sample. Surprisingly, the results indicate that CAAR for the President's signature event is negative which is contrary to what we have predicted. However, hypothesis ( $\mathrm{H} 2 \mathrm{a})$ is not supported as the $\mathrm{Z}$ score is not significant and we are cautious about its interpretation. The results also show that $\mathrm{H} 2 \mathrm{~b}$, which is our main hypothesis regarding the Supreme Court decision to uphold the health care law is supported. CAAR is positive and highly significant as we have expected. This indicates that Supreme Court decision has a positive impact on hospitals as they will gain more customers and increase profitability.

It is interesting to see that CAAR sign has changed from negative (although not significant) when the law was enacted in 2010 to positive in 2012 after the announcement of the Supreme Court decision. It is likely that hospitals have realized the benefits of the new law as time has passed by and their uncertainty level has been reduced. Surprisingly, however, establishing 


\section{Ml Macrothink}

International Journal of Accounting and Financial Reporting ISSN 2162-3082 2013, Vol. 3, No. 1

hospitals' value based program has very little impact on hospitals. CAAR is close to zero and the $\mathrm{Z}$ score is not significant. Since the hypothesis is not supported, we cautiously suggest that this program is not of concern to most hospitals.

Table 4: Hospitals' CAAR and Gen Z scores

\begin{tabular}{|l|l|l|}
\hline Event & CAAR \% & Gen Z \\
\hline President Obama signed the law & -3.65 & -0.96 \\
\hline Supreme Court decision & 3.06 & $2.438^{*}$ \\
\hline Establishing Value Based System & 0.05 & 0.777 \\
\hline
\end{tabular}

*Significant at 0.01 level

The results in Table 5 indicate that despite the fact that H3a is not supported, CAAR is positive as we have predicted. We cautiously contend that positive CAAR may reflect the positive impact signing the reform into law has on brand-name drug firms. As we have expected, H3b is supported. Requiring brand-name pharmaceutical companies to offer senior citizens discounts has a negative effect on drug companies. Closing the donut hole is a chore which brand-name drug makers dislike because it reduces their profit. The results also show that $\mathrm{H} 3 \mathrm{c}$ is supported. CAAR is positive and highly significant. This shows that the Supreme Court decision has positive implications for brand-name drug makers. More people will purchase their drugs and thus their profit will increase.

Table 5: Brand-name drug makers' CAAR and Gen Z scores

\begin{tabular}{|l|l|l|}
\hline Event & CAAR \% & Gen Z \\
\hline President Obama signed the law & 0.41 & 1.005 \\
\hline Offering seniors discounts to close donut hole & -0.66 & $-2.777^{*}$ \\
\hline Supreme Court decision & 1.39 & $2.747 * *$ \\
\hline
\end{tabular}

*Significant at 0.01 level $* *$ Significant at 0.01 level

Table 6 below presents CAARs and Generalized Z scores for generic drug makers. The results show that H4a is supported. The President's signature of the health care reform into law has a negative effect on generic drug makers. CAAR is $-1.59 \%$ and the $\mathrm{Z}$ score is -1.713 which is significant at the 0.05 level. Although $\mathrm{H} 4 \mathrm{~b}$ is not supported, CAAR is negative as 
we have expected. We cautiously conjecture that the negative CAAR may reflect the negative impact of this provision. Requiring generic drug manufactures to offer seniors discounts and to close the donut hole lowers profits. This provision of the law also costs billions of dollars to implement and generic drug makers have to finance a large portion of it. H4c, which concerns our main event, is not supported. As this hypothesis is not supported, we are cautious about drawing any inferences. Nonetheless, this result could probably mean that the Supreme Court decision has very little effect on generic drug makers.

Table 6: Generic drug makers'CAAR and Gen Z scores

\begin{tabular}{|l|l|l|}
\hline Event & CAAR \% & Gen Z \\
\hline President Obama signed the law & -1.59 & $-1.713^{*}$ \\
\hline Offering discounts to seniors to close donut hole & -0.82 & -0.43 \\
\hline Supreme Court decision & 0.14 & 0.758 \\
\hline
\end{tabular}

*Significant at 0.05 level

\section{Conclusion}

The results of our study show that the new health care law has a negative effect on health insurance companies. The enactment of the law, requiring insurers to cover customers with pre-existing conditions and to close the donut hole, and the Supreme Court decision to uphold the law (to some extent) have negatively impacted health insurance firms. The new law requires health insurers to lower their profits and to follow prescribed rules and regulations. Also, the signing of the law has negatively affected generic drug makers. The Supreme Court decision and offering seniors discounts seem to have very little impact on generic drug makers.

On the other hand, the Supreme Court decision to uphold the law has a positive effect on hospitals as well as brand-name drug makers. They are expected to benefit from the law and their profits are expected to rise. Establishing hospitals' value-based program seems to have very little impact on most hospitals. Requiring brand-name drug makers to offer seniors discounts has a highly significant negative effect on them because it reduces their profit margins.

Based on our study results, we can make several recommendations. First, we recommend that insurance companies try to find creative ways to cut their expenses to ensure sustainable profitability. For example, they could utilize more technological advances and efficient medical equipment. Second, we suggest that hospitals take advantage of the law and the millions of expected new customers to enhance their financial position and invest in better technologies and medical services. Third, brand-name drug makers should utilize the benefits of the law and invest some of the additional expected profits in creating less expensive and affordable drugs which the average American can afford. Fourth, we suggest that generic 
drug makers should exert more effort in developing more competitive drugs at an affordable price. They should also use better technologies to lower their costs to be able to compete with brand-name drug makers. Fifth, we recommend that policy makers take into account the impact (whether positive or negative) of the law and its provisions on health insurers, hospitals, brand-name drug makers and generic drug makers when formulating national policies.

\section{References}

Abelson, R. (2010). In health care overhaul, boons for hospitals and drug makers. The New York Times. Retrieved from http://www.nytimes.com/2010/03/22/business/22bizhealth.html?pagewanted=all.

Abraham, S. \& Voos, P. B. (2005). The market's reaction to two Supreme Court rulings on American labor law. Journal of Labor Research, 26, 677-687.

Amadeo, K. (2012). Obamacare Bill: A summary of the Bill's 10 titles. About.com. Retrieved from http://useconomy.about.com/od/healthcarereform/a/Obamacare-Bill.htm.

Armitage, S. (1995). Event study methods and evidence on their performance. Journal of Economic Surveys, 9, 25-52.

Baghaeimehr, S. (2012). Under ObamaCare, is it illegal for insurance companies to deny coverage for health reasons?Sofi Insurance Services.Retrieved from http://www.lahealthcoverage.com/under-obamacare-is-it-illegal-for-insurance-companies-to-d eny-coverage-for-health-reasons.html.

Baker, P. (2012). Obama was pushed by drug industry, emails suggest. The New York Times. Retrievedfromhttp://www.nytimes.com/2012/06/09/us/politics/e-mails-reveal-extent-of-obam as-deal-with-industry-on- health-care.html?pagewanted=all\&_r=0.

Ball, R. \& Brown, P. (1968). An empirical evaluation of accounting income numbers. Journal of Accounting Research, 6, 159-178.

Beeson, E. \& Todd, S. (2012). Health care ruling brings disappointment, but certainty to New Jersey business leaders.NewJersey. Retrieved from http://www.nj.com/business/index.ssf/2012/06/health_care_ruling_brings_disa.html.

Boehmer, E., Broussard, J. P., \& Kallunki, J. (2002). Using SAS in financial research. Cary, NC: SAS Institute Inc.

Brubaker, H., Burling, S., Sell, D., \& Von Bergen, J. (2012). Hospitals delighted by high court's ruling; other health care sectors mixed. Philly Business Articles. Retrieved from

http://articles.philly.com/2012-06-30/business/32473199_1_medicaid-expansion-health-cover age-subsidized-coverage.

Daily Iowan Editorial Board (2012). Not denying pre-existing conditions most important. Retrieved from http://www.dailyiowan.com/2012/10/18/Opinions/30396.html. 


\section{Al Macrothink}

International Journal of Accounting and Financial Reporting ISSN 2162-3082 2013, Vol. 3, No. 1

Deschenes, S. (2012). 3 ways hospitals can get most from value-based purchasing. Healthcare IT News. Retrieved from http://www.healthcareitnews.com/news/3-ways-hospitals-can-get-most-value-based-purchasi ng.

Drew, C. F. \& Burt, J. C. (2011). Dealing with the Medicare doughnut hole. Health Capital Consultants. Retrieved from http://www.healthcapital.com/hcc/newsletter/12_11/hole.pdf.

Events Study (2012). Eventus: Software for event studies \& financial market research. Retrieved from http://www.eventstudy.com/.

Fama, E. F. (1970). Efficient capital markets: a review of theory and empirical work. Journal of Finance, 25, 383-417.

Fama, E. F., Fisher, L., Jensen, M.C., \& Roll, R. (1968). The adjustment of stock prices to new information. International Economic Review, 10, 1-21.

Favole, J. A. (2010). For drug makers, closing doughnut hole promises silver lining. Wall Street Journal. Retrieved from http://online.wsj.com/article/SB10001424052748704094104575143961683850340.html.

Freedman, M. \& Stagliano, A. J. (1991). Differences in social-cost disclosures: A market test of investors reactions. Accounting, Auditing \& Accountability Journal, 4, 68-83.

Golec, J. \& Vernon, J. (2012). What's the "interest" in FDA drug advisory committee conflicts of interest? The National Bureau of Economic Research. Retrieved from http://www.nber.org/papers/w14932.

Grand Old Party (2012). The case against ObamaCare. Retrieved from http://www.gop.com/news/research/the- case-against-obamacare/.

Hamilton, W. \& Tangel, A. (2012). Supreme Court ruling causes big swings in healthcare stocks. Los Angeles Times. Retrieved from http://articles.latimes.com/2012/jun/29/business/la-fi-health-stocks-20120629.

HealthCare(2010). Medicare drug discounts. Retrieved from http://www.healthcare.gov/law/features/65-older/drug-discounts/index.html.

Health Care (2012). Retrieved from http://www.healthcare.gov/law/timeline/.

Horwitz, J. R., \& Levy, H. (2012). Obamacare will help drive down health care costs. CNN.

Retrieved from http://www.cnn.com/2012/06/28/opinion/horwitz-levy-obamacare/index.html.

Ignjatovic, T. (2010). Mixed outlook for pharmaceutical industry following healthcare reform, Datamonitor (DTM.L)Reports.BioSpace.Retrieved http://www.biospace.com/news_story.aspx?StoryID=174792\&full=1.

Insurance Journal (2012). Agents cite advance in fight against medical loss ratio. Retrieved from http://www.insurancejournal.com/news/national/2012/09/20/263803.htm. 
Jayakumar, A. \& Kliff, S. (2012). Stocks dip, then recover on Supreme Court's health-care decision. The Washington Post. from http://www.washingtonpost.com/business/economy/stocks-dip-then-recover-on-supreme-cour ts-health-care-decision/2012/06/28/gJQAn0wFAW_story.html.

Kaiser Family Foundation (2012). Health Reform Source. Retrieved from http://healthreform.kff.org/timeline.aspx.

Kavilanz, P. (2010). Health care: Patients, doctors, insurers react. CNN Money. Retrieved from

http://money.cnn.com/2010/03/22/news/economy/health_care_reform_industry_reactions/ind ex.htm.

Kavilanz, P. (2012). Health care reform stands: How it impacts your coverage. CNN Money. Retrieved from http://money.cnn.com/2012/06/28/pf/health-care-reform-insurance/index.htm.

Khimm, S. (2009). Will the White House-Pharma deal survive? The New Republic. Retrieved from http://www.tnr.com/blog/the-treatment/will-the-white-house-pharma-deal-survive.

Kothari, S. P. \& Warner, J. B. (2005). Econometrics of event studies, Chapter 1 in B. Espen Eckbo (ed.), Handbook of Corporate Finance: Empirical Corporate Finance (Handbooks in Finance Series, Elsevier/North- Holland).

Krantz, M. (2012). Health care reform winner: Hospital stocks; Loser: Insurers. USA Today. Retrievedfrom

http://usatoday30.usatoday.com/money/perfi/columnist/krantz/story/2012-07-17/health-care-r eform-stock-winners-losers/56279076/1.

Kristof, K. (2012). What the Supreme Court's ruling means for health care stocks. Kiplinger's Personal Finance. Retrieved from http://www.kiplinger.com/columns/picks/archive/health-care-reform-stocks-supreme-courtaffordable-care-act.html.

McWilliams, A., Turk, T. A., \& Zardkoohi, A. (1993). Antitrust policy and mergers: The wealth effect of Supreme Court decisions. Economic Inquiry, 31, 517-533.

Mellor, G. M. (2009). Erasing the doughnut hole for all seniors-A Senate revolt against big pharma brewing. The Huffington Post. Retrieved from http://www.huffingtonpost.com/gail-mcgowan-mellor/erasing-the-doughnut-hole_b_295773. html.

Mukherjee, S. (2012). New hospital reforms under Obamacare aim to ensure quality care. Think Progress Organization. Retrieved from http://thinkprogress.org/health/2012/10/01/932201/two-new-obamacare- hospital-reforms/.

Mullin, G. L., Mullin, J. C., \& Mullin, W. P. (1995). The competitive effects of mergers: Stock market from the U.S. Steel dissolution suit. The RAND Journal of Economics, 26, 314-330. 


\section{Macrothink}

International Journal of Accounting and Financial Reporting ISSN 2162-3082 2013, Vol. 3, No. 1

Peterson, P. P. (1989). Event studies: A review of issues of methodology. Quarterly Journal of Business and Economics, 28, 36-66.

Reuters (2012). Factbox: Winners, losers in House healthcare bill. Retrieved from http://www.reuters.com/article/2010/03/22/us-usa-healthcare-industry-factbox-idUSTRE62K 1IV20100322.

Rogoff, A. C. \& Yerramalli, A. (2012). Is Obamacare the right prescription for insolvent hospitals? New York Law Journal.Retrieved

from http://www.newyorklawjournal.com/PubArticleNY.jsp?id=1202572121738\&Is_Obamacare_t he_Right_Prescription_for_Insolvent_Hospitals\&slreturn=20130021180438.

Sebelius, K. (2010). New help for seniors who fall into the Medicare donut hole: 50\% discount starts in 2011. Health Care Website. Retrieved from http://www.healthcare.gov/blog/2010/09/donuthole- 50percentdiscount.html.

Shannon, K. (2010). Drug companies and hospitals get a boost from healthcare reform. Money Morning. Retrieved from http://moneymorning.com/2010/03/24/healthcare-reform-3/.

Silverman, E. (2012). What the Supreme Court ruling means for pharma. Forbes. Retrieved fromhttp://www.forbes.com/sites/edsilverman/2012/06/28/what-the-supreme-court-ruling-me ans-for-pharma/.

Smith, A. (2012). Health care stocks divided after ruling. CNN Money. Retrieved from http://money.cnn.com/2012/06/28/investing/healthcare-stocks/index.htm

Terkel, A. (2012). Democrats go on offense on Obamacare, hit GOP for pushing repeal of popular provisions. The Huffington Post. Retrieved from http://www.huffingtonpost.com/2012/07/10/democrats-obamacare-repeal_n_1662716.html.

Trager, R. (2010). Big pharma scores in U.S. healthcare reform. Royal Society of Chemistry. Retrieved from http://www.rsc.org/chemistryworld/News/2010/March/25031003.asp.

Ungar, R. (2012). Busted! Health insurers secretly spent huge to defeat health care reform while pretending to support Obamacare. Forbes. Retrieved from http://www.forbes.com/sites/rickungar/2012/06/25/busted-health-insurers-secretly-spent-huge -to-defeat-health-care-reform-while-pretending-to-support-obamacare/.

U.S. Department of Health and Human Services (2011). At risk: Pre-existing conditions could affect 1 in 2 Americans: 129 million people could be denied affordable coverage without health reform. Retrieved from http://aspe.hhs.gov/health/reports/2012/pre-existing/index.shtml.

Young, J. (2012). Health care reform rebates for health insurance costs rolling in. The Huffington Post. Retrieved from http://www.huffingtonpost.com/2012/07/16/health-care-reform-rebate_n_1676964.html.

Zacks (2012). Retrieved from http://www.zacks.com/. 